Article

\title{
Investigating Web-Based Sustainability Reporting in Italian Public Universities in the Era of Covid-19
}

\author{
Giuseppe Nicolò $^{1}$ (D), Natalia Aversano ${ }^{1, *(\mathbb{D})}$, Giuseppe Sannino ${ }^{2}$ and Paolo Tartaglia Polcini ${ }^{1}$ (D) \\ 1 Department of Management and Innovation Systems, University of Salerno, Via Giovanni Paolo II, 132, \\ 84084 Fisciano (SA), Italy; gnicolo@unisa.it (G.N.); ptpolcini@unisa.it (P.T.P.) \\ 2 Economics Department, University of Campania "Luigi Vanvitelli", Corso Gran Priorato di Malta, \\ 81043 Capua (CE), Italy; giuseppe.sannino@unicampania.it \\ * Correspondence: naversano@unisa.it
}

check for updates

Citation: Nicolò, G.; Aversano, N.; Sannino, G.; Tartaglia Polcini, P. Investigating Web-Based Sustainability Reporting in Italian Public Universities in the Era of Covid-19. Sustainability 2021, 13 , 3468. https://doi.org/10.3390/ su13063468

Academic Editor:

Isabel-María Garcia-Sanchez

Received: 23 February 2021

Accepted: 18 March 2021

Published: 21 March 2021

Publisher's Note: MDPI stays neutral with regard to jurisdictional claims in published maps and institutional affiliations.

Copyright: (c) 2021 by the authors. Licensee MDPI, Basel, Switzerland. This article is an open access article distributed under the terms and conditions of the Creative Commons Attribution (CC BY) license (https:// creativecommons.org/licenses/by/ $4.0 /)$.

\begin{abstract}
Universities are increasingly called to demonstrate to stakeholders their active commitment to responding to social and environmental issues through comprehensive reporting practices. Such expectations were further enhanced by the recent pandemic outbreak unleashed by coronavirus disease 2019 (COVID-19), which has bolstered social pressures on universities to demonstrate their active engagement in supporting health systems in fighting against the virus as well as in ensuring adequate e-learning paths for students. Therefore, this study aims to investigate to what extent Italian public universities disclose sustainability information on their websites. The study is based on a well-established framework adapted from the literature. The category "Sustainability and COVID-19" has been added to also examine the extent to which universities disclose information regarding policies and strategies adopted to cope with the ongoing pandemic crisis. Results evidence that most of the sampled universities devote a specific section of their websites to disclose information on sustainability issues. Results also highlight a strong commitment to the disclosure of social issues. Particular attention is devoted to disclosing information about "Social Performance"; "Sustainability and COVID-19" and "Society Issues". The results may be beneficial to both policymakers and university governors in gaining awareness about the potential of websites in engendering insights into the social issues that involve a university and a wider range of stakeholders.
\end{abstract}

Keywords: sustainability reporting; sustainable development; Italian universities; COVID-19; social and environmental disclosure

\section{Introduction}

As entities responsible for knowledge creation, development and dissemination, universities are being increasingly expected to incorporate sustainable development (SD) policies and principles both in education and research activities and to assume a crucial role in responding to emerging sustainability issues [1-3]. In turn, universities are called to demonstrate to stakeholders and society how they commit to responding to social and environmental issues through comprehensive reporting practices [4,5]. Such expectations were further enhanced by the recent pandemic outbreak unleashed by coronavirus disease 2019 (COVID-19). COVID-19 is creating adverse health externalities, triggering risks and losses for each type of organization and society at large [6,7]. The pandemic has imposed new challenges to organizations' sustainability practices due to its multiple effects on employees, supply chain and external relationships with customers, which have involved a rethinking in management and reporting practices [6,7]. In particular, it has bolstered social pressures on universities to demonstrate their active engagement in supporting health systems in fighting against the virus and ensuring adequate e-learning paths for students.

With the COVID-19 pandemic, universities have been spurred to adopt innovative and sustainable models to ensure the continuity of teaching, research and third mission activities and to take a primary role in supporting the local communities to deal with the 
pandemic. As well, through their institutional activities, universities are called upon to breathe innovative paradigms of sustainability into their students.

As a result, the adoption of adequate sustainability reporting (SR) practices, illustrating stakeholders the most salient economic, social and environmental impacts of universities' activities and the efforts made to foster SD [8-10] is, now, more than ever, expected to become the norm and not the exception in the higher education system. SR practices range from the traditional annual report to stand-alone reports (e.g., Corporate Social Responsibility (CSR) reports or SR) drafted in compliance with Global Reporting Initiative (GRI) standards [9]. However, scholars [2,4,10] have highlighted that SR practices in the university context are still in an embryonic stage both in terms of the number of universities reporting and the significance of the information provided to stakeholders.

Recently, scholars [11,12] have discussed the opportunity to exploit the potential of information and communication technologies (ICT) and digital innovations to overcome the limitations of traditional stand-alone SR and stimulating universities to adopt a more proactive approach towards sustainability disclosure. In particular, the Internet and websites-whose structure and potentialities have dramatically improved following the recent digital revolution - can play a pivotal role in transmitting the sustainability discourse from universities to the external environment [11,12]. Websites' use to convey information is expected to improve dialogue, interactivity, and universities' engagement with stakeholders [13-15]. Accordingly, websites allow universities to meet the different stakeholders' expectations about financial and non-financial issues and legitimize their actions in society $[10,12]$.

In the wake of such arguments, this research provides two-fold contributions to existing literature.

Firstly, it explores an alternative communication tool, a website, to examine to what extent Italian public universities disclose sustainability information, including, economic, social and environmental impacts of their activities. To this end, using content analysis, the largest Italian public universities' websites have been analyzed to evaluate the presence or absence of sustainability information.

Secondly, while drawing upon a framework adopted in prior similar studies $[5,12,16]$, this research provides an innovative overview of the online disclosure of initiatives and actions taken by Italian public universities in response to COVID-19.

Therefore, this study answers the call for more in-depth research on social and environmental disclosure in universities $[9,16]$. Italy is considered a relevant case study because the journey towards SR practices is maturing rapidly, capturing academics' attention who are increasingly debating this topic $[4,5,17]$.

The remainder of the paper is arranged as follows. The next section contains a review of the literature on SR, paying particular attention to sustainability initiatives and reporting in higher education institutions (HEIs). The third section outlines the research methodology applied, while the fourth section presents and discusses the research results. Last, the concluding remarks focus on the implications and limitations of the research

\section{Literature Review}

\subsection{Sustainability Initiatives and Reporting in Higher Education Institutions}

Sustainability and SD are relevant topics in society as social and environmental problems worldwide (i.e., child labour, food security, and air pollution) represent big concerns.

Several initiatives contribute to the development of sustainability, evidencing the university's central role (e.g., United Nations (UN) Decade of Education for Sustainable Development 2005-2014, UN World Action Program Education for Sustainable Development). Moreover, numerous sustainability-related international declarations in the higher education system have been drafted and co-signed over the years, such as Tbilisi's declarations, Talloires Halifax and Lüneburg; the Copernicus Charta and RIO+ 20 [18].

According to Europe 2020, the university can make a significant contribution to intelligent growth and SD in Europe as a vehicle for social change [5].The United Nations-with 
17 SD Goals-pointed out the importance of incorporating these targets in the education process to train future graduates who will manage companies and other organizations $[12,18]$.

Therefore, regarding sustainability, universities have a two-fold mission: first, they have the responsibility to inculcate the concept of sustainability and SD in their students through teaching, research and outreach activities; second, they are called to reduce the environmental impact of their operations via sustainable activities and initiatives $[5,12,16,18]$. In this sense, SR represents a useful means for universities to communicate their efforts and sustainable progress to the university community [8].

The theoretical perspective underpinning the current study is legitimacy theory. This theory asserts a "social contract" between organizations and the community where they operate; more specifically, organizations should attempt to comply with social expectations and norms considered legitimate by the community where they act $[6,12,19]$. Based upon legitimacy theory, universities, as public sector organizations, should not only operate sustainably but should also report their sustainability-related initiatives and efforts in order to meet the expectations of various stakeholders in society, and further to achieve the status of legitimacy in the community where they operate $[9,12]$.

Therefore, the growing need for accountability about the use of the university's resources, the need to improve the image of the organization, and the awareness of the relevance of sustainability issues have fostered the implementation of new accounting instruments designed to measure the different dimensions of universities' activities in addition to the traditional economic and financial measures [5].

However, this evolutionary path of SD implementation at universities has regarded not only reporting practices but also their organizational strategies [5]. These reports should detail what has been achieved against previously identified targets [9].

The sustainability concept should be institutionalized amongst universities [20]. Accordingly, Alonso-Almeida et al. [18] (p. 145) contend that sustainability pillars at universities can be internalized by: «transforming their own missions, restructuring their curricula, modifying their research programs, introducing new ways to live on their campuses, promoting community engagement and outreach and, finally assessing and reporting these activities to stakeholders».

Therefore, the improvement of universities' SR practices enhances the disclosure quality about the organization's performance and increases dialogue with stakeholders. To achieve this aim, several studies have pointed out the greater importance of online disclosure on university websites of universities' social responsibility [11,12].

Under the third mission of universities, with a participative approach of citizens in SD implementation and reporting, these tools can also be useful in enhancing SD knowledge in the local community [5].

\subsection{Previous Studies on Sustainability Reporting in Universities}

In recent years, several universities have voluntarily started to report their sustainabilityrelated efforts and initiatives through various communication channels, such as the annual report, a stand-alone sustainability report, or the Internet. The reporting of sustainability activities and initiatives should help universities meet various stakeholders' information needs and legitimize themselves to be crucial actors in society for sustainability and SD [2,12]. However, despite its potential for supporting SD's goal, universities still lag on SR [9].

The lack of law and common standards has led to the development of documents that differ across universities in their structure, disclosure level and standards compliance [12]. Although the GRI provides SR guidelines widely accepted for some specific sectors, the need to issue SR's guidelines specifically addressing the university sector has been discussed at length $[9,21]$.

In the last decades, a growing number of studies focused attention on SR at universities in a variety of contexts $[1,2,4,5,9,10,12,16,18,20,22]$. 
Some research was mainly concerned with performance measurement, developing and applying some assessment models such as STARS (the Sustainability Tracking, Assessment and Rating System) and GASU (the Graphical Assessment of Sustainability in Universities) [23]. However, most of the prior research investigated the level and type of sustainability and social disclosure analyzing the annual report or the stand-alone sustainability report $[1,5,8,9,16,18,22]$. More specifically, in the Canadian context, Fonseca et al. [16] evidenced that SR is an uncommon and diverse practice at Canadian universities. These documents can be seen more as a tool to emphasize eco-efficiency rather than to inform sustainability-oriented decisions.

In the Australian context, Gamage and Sciulli [9] observed that few Australian universities provide sustainability information in stand-alone sustainability reports and that some universities provide information both in the annual reports and dedicated websites. The majority of them include information on sustainability vision, strategy, and leadership, giving a strong focus on the environmental category and paying little attention to other dimensions.

In the Italian context, both Del Sordo et al. [4] and Moggi [5] evidenced that the spread of SR did not have a consistent trend. Moreover, Moggi's [5] study reveals that GRI guidelines have been employed with national standards by Italian universities, providing more comprehensive reports, which are difficult to assure and compare. The study of Del Sordo et al. [4] reveals that the main barrier in SR's development was the lack of systematic collection of non-financial information within the university.

Some studies have pointed out that university websites may represent a relevant field to retrieve information about the university's sustainability action and strategy [11-13].

More specifically, the study of An et al. [12] shows that most universities have a specific webpage for SR on their website; in this section, universities provide a consistent amount of sustainability-related information in terms of general and specific aspects and stakeholder participation. Moreover, most universities employ various information and communication technologies (i.e., separate emails, online forums and social media) to interact with stakeholders regarding sustainability issues.

\section{Research Methodology}

\subsection{Research Context and Sampling Process}

Italian public universities may represent an appropriate case study opportunity as, in last few decades, the Italian higher education system has been affected by a massive process of changes inspired by the neo-liberal movement of New Public Management $[3,4,24]$. Such changes have profoundly impacted the governance, management, and accounting systems of universities, stressing the need for greater financial and organizational self-sufficiency and higher levels of transparency and accountability to stakeholders [4,22,24]. Italy also has long-standing experience with SR practices [17]. In particular, since the early 2000s, both policymakers and non-governmental organizations have provided many efforts to promote voluntary SR practices among public sector entities to expand accountability boundaries from financial to non-financial issues in the interest of the different stakeholders' communities [4,17]. Accordingly, a Directive was issued in 2006 by the Italian Minister for Public Affairs [25] to promote the social report's adoption among public sector organizations. The Directive also proposes guidelines that suggest principles, structure and contents for drafting a social report [22]. Also, the National Group for Social Reporting (GBS) is an Italian non-profit research association composed of a network of academics, practitioners, and auditors interested in social reports. Since its foundation in 1997, the GBS has promoted a social responsibility culture among private and public sector entities. The main output of GBS activity is represented by a series of guidelines and research documents aimed at supporting voluntary social reporting practices. In particular, in 2008 the GBS released the "research document n. 7-Social reporting in universities", which defines the structure and content of the social report for Italian public universities [26]. According to the document, the social report should provide stakeholders with a comprehensive portrayal of university 
activities and results and should consist of at least three sections: (1) university identity; (2) reclassification of financial data; and, (3) social issues [26].

In more recent years, in keeping with the 2030 Agenda for SD, Italian universities have embarked on a necessary process of driving the transition towards the SD of local communities and territories. To this aim, in 2015 the Council of Italian Rectors (CRUI) has promoted the creation of the Network of Universities for Sustainable Development (Rete delle Università per lo Sviluppo sostenibile, RUS). The main objective of the RUS is to promote the adoption of best practices of sustainability both inside and outside the universities, sharing skills and experiences which may increase the positive impacts exerted by the individual actions implemented by each university [27]. The RUS is also committed to promoting the adoption of SDGs and in contributing to their achievement.

Given these arguments, the sampling process started by considering all Italian public universities, including high schools and PhD schools (68). However, in keeping with prior literature [16], we selected the largest Italian public universities by student enrolment. According to Fonseca et al. [16], "Enrolment provides an indirect indication of campus area, endowment funds, and intensity of teaching and research". Moreover, the largest universities are more politically visible and more subject to social pressures than smaller ones. Thereby, they have to face a wide forum of stakeholders whose interests are at stake and whose heterogeneous information needs require special attention in terms of disclosure practices $[2,14,24]$.

Therefore, based on the CENSIS (Social investment study centre-Centro Studi Investimenti Sociali) ranking, we selected the 10 largest universities, considered "mega atenei", having more than 40,000 students.

\subsection{Data Collection and Coding Framework}

Once we identified the sample, a content analysis was performed to determine the extent to which Italian public universities provide voluntary information on sustainability via websites. Content analysis is «a method of codifying the text (or content) of a piece of writing into various groups or categories depending on the selected criteria. Following coding, quantitative scales are derived to permit further analysis» [28] (p. 489). Content analysis is used because it represents one of the most widespread research methods adopted in social and environmental disclosure studies in private and public sector entities (e.g., local governments and universities) $[9,12,14]$. Moreover, it is considered a reliable, faster, objective, and cheaper method to collect publicly available data from different sources $[2,3,14]$.

The websites were selected as data sources to conduct content analysis. Following the ongoing digital transformation, websites are increasingly seen as an alternative to providing information on sustainability issues and improving social dialogue with stakeholders $[12,13,15]$. In particular, the Internet offers universities the chance to satisfy stakeholders' information needs in a more accessible, timely and interactive way, improving the transparency and accountability about both financial and non-financial issues $[11,12,14]$. The use of the Internet also encourages stakeholders' engagement in the university's decision-making process, enhancing their trust and confidence [11]. In keeping with previous studies [11,14], only web pages in web browser format (e.g., HTML) were content analyzed to collect sustainability information. Other documents available on websites in PDF or Word form, such as annual, social or sustainability reports; were excluded as they were considered separate information sources [14]. To perform an exhaustive review of university webpages and consider the effects of the pandemic outbreak on university web disclosure strategies, data collection took place between August and September 2020.

In order to testify to what extent universities are exploiting websites' potential as a means of communicating their sustainability performance, some preliminary aspects of their webpages have been analyzed. In particular, we searched for: (1) the presence of a specific section devoted to the sustainability issue; (2) information regarding the presence of a specific sustainability office/committee at the university; (3) the presence of a regular 
stand-alone social/sustainability report, and; (4) the presence of a specific section devoted to COVID-19 issues.

To improve the study's reliability and comparability, the content analysis was performed following a framework adopted in prior similar studies $[5,12,16]$ and inspired by internationally recognized GRI guidelines. The framework consists of 56 items grouped in 10 categories. However, some amendments were applied to the original coding instrument. These were made to consider the peculiarities of the tool to be analyzed-the websites-and the recent pandemic that influenced sustainability issues to be disclosed.

Accordingly, the category "reporting approach" has been deleted as it includes information strictly related to the draft of stand-alone sustainability reports based on GRI requirements (e.g., reporting period; reporting standard; external assurance). Also, the category "economic performance" has been removed as it contains information that can be more easily retrievable from annual reports. Similarly, the category "Green buildings and procurement" has been deleted as it contains information that are typically included in the social or sustainability report more than on the universities' websites.

By contrast, the category "Sustainability and COVID-19" has been added to examine the extent to which universities disclose information regarding policies and strategies adopted to cope with the pandemic crisis. This choice was motivated by the fact the COVID-19 is affecting all dimensions of university sustainability and universities' progress towards the achievement of SDGs. Thus, this category includes the following six items: (1) remote/online teaching activities; (2) counselling and psychological support; (3) prevention measures; (4) COVID-19 research projects; (5) smart working; (6) crowdfunding/fundraising for COVID-19.

As a result, a final list of 49 items grouped in 8 categories was obtained, as shown in Table 1.

Table 1. University sustainability coding framework.

\begin{tabular}{|c|c|}
\hline (1) Organization profile and governance & (5) Society issues \\
\hline Statement from the president & Impacts on community \\
\hline Description of the organization & Corruption \\
\hline Governance structure or processes & Public policy \\
\hline Commitments to external sustainability initiatives & Anti-competitive behaviour \\
\hline Stakeholder engagement & Compliance with general legislation \\
\hline (2) Environmental performance & (6) Research on sustainability topics \\
\hline Material & Policies related to sustainability in research \\
\hline Energy & Research centres/labs related to sustainability \\
\hline Water & Sustainability-related research programs \\
\hline Biodiversity & Incentives to sustainability research \\
\hline Emissions, effluents and wastes & Funding and grants for sustainability research \\
\hline Compliance with environmental legislation & Academic production related to sustainability \\
\hline Transportation & Sustainability-related research projects \\
\hline \multicolumn{2}{|l|}{ Environmental expenditures } \\
\hline (3) Social performance & (7) Curriculum and teaching on sustainability topics \\
\hline Employment & Policies related to sustainability in the curriculum \\
\hline Labour/management relations & Courses related to sustainability \\
\hline Occupational health and safety & Students taking sustainability-related courses \\
\hline Training and education & Sustainability literacy assessment \\
\hline \multirow[t]{3}{*}{ Diversity and equal opportunity } & Degree programs related to sustainability \\
\hline & Non-curricular teaching initiatives related to sustainability \\
\hline & Scholarships offered to sustainability-related education \\
\hline (4) Human rights issues & (8) Sustainability and COVID-19 \\
\hline Investment and procurement policy & Remote/online teaching activities \\
\hline Non-discrimination & Counselling and psychological support \\
\hline Freedom of association and collective bargaining & Prevention measures \\
\hline Child labour and forced labour & COVID-19 Research projects \\
\hline Security practices & Smart working \\
\hline Indigenous rights & Crowdfunding/fundraising for COVID-19 \\
\hline
\end{tabular}


To quantify the information gathered through the content analysis and assess the level of sustainability disclosure provided universities, a binary dichotomous scoring system was applied. Accordingly, we checked for the absence/presence (0/1) of each item-included in the coding framework-on the sampled university website $[2,12,14]$. This approach attributes the same importance to all the items examined and reduces potential subjectivity problems $[3,11,12]$.

Last, to ensure reliability, the process was performed separately by two authors of this paper on five websites. Once completed, the authors met to discuss the results, clarify doubts and solve discrepancies. This step allows authors to achieve maximum consensus and objectivity.

\section{Results and Discussion}

\subsection{General Aspects of Web-Based Sustainability Reporting}

Table 2 provides evidence that 7 universities out of $10(70 \%)$ devote a specific section of their websites to illustrate sustainability issues. This testifies that universities exploit websites' potential in terms of accessibility, graphic and immediacy to create a sense of transparency among stakeholders and gain their legitimacy by communicating their sustainability performance $[1,9,12]$. However, the extent and the significance of content included in the specific webpage related to sustainability varies between universities. While some universities focus only on specific issues such as waste management and sustainable mobility, others provide a link to stand-alone webpages. They illustrate plan, projects, and initiatives carried out to deal with the different dimensions of sustainability. For instance, a university provides a link to a webpage named "Multicampus sostenibile" which, for each sustainability issue (energy; mobility; environment; social issues), illustrates both objectives and activities undertaken to reach them through narratives and images. The case of a university which present a specific portal "Ateneo sostenibile" is also very interesting. This portal discloses qualitative and quantitative information about the policies implemented to deal with the different sustainability dimensions (e.g., materials; energy; waste; green spaces and green buildings), also evidencing learning paths and research projects linked to sustainability matters. Therefore, it provides users with useful information about how the university integrates sustainability concerns in their degree courses, curricula and research projects.

Table 2. General aspects of online sustainability reporting.

\begin{tabular}{ccc}
\hline General Aspects & $\mathbf{N}$ & \% \\
\hline Presence of a specific section devoted to sustainability issues & 7 & $70 \%$ \\
\hline Information regarding the presence of a specific sustainability office/committee at the university & 7 & $70 \%$ \\
\hline Presence of a regular stand-alone social/sustainability report & 6 & $60 \%$ \\
\hline Presence of a specific section devoted to COVID-19 issues & $60 \%$ \\
\hline
\end{tabular}

Source: adapted from [12].

Interestingly, 7 universities out of 10 provide information concerning the presence of an office/committee which specifically deals with sustainability issues. The majority of universities, recognize such a unit as a "Green Office", attributing to it tasks that prevalently involve planning, implementation, coordination and monitoring of projects and policies of environmental sustainability (e.g., water treatment; waste management; renewable energy sources; materials; mobility; green spaces and green buildings). A university attributes the green office the specific task to "reduce the university's environmental impact by involving and engaging the entire university community". Another university defines the green office as a "space for discussion and development of projects, managed by the students in tune with the professors and the university's technical-administrative staff to promote the culture of sustainability and implement concrete programs plans". Thus, the communication of a green office's presence seems to be an important instrument to 
enhance university stakeholders' engagement and creates common paths for sustainable value creation. The analysis of the presence of a regular stand-alone social/sustainability report provides a mixed picture that shows that Italian public universities are far from homogenous in the way they approach sustainability reporting practices [4,5]. A first shortcoming arises from the terminology used for the report, which influences its contents and significance. Two universities used the term "social report" in line with Italian GBS and public sector guidelines. Three universities adopt a terminology more compliant with GRI guidelines "sustainability report". Furthermore, one university in 2016 merged its gender report and social report, and starting from 2018 had an integrated gender, social and sustainability report in a unique document.

A second weakness is related to the patchy trend, which emerges from the sustainability report's adoption in the university context. This is the case of a university that drafted its first sustainability report in 2018 in contrast with a university that shows a longer history of regular, annual social reports adopted since 2012. There is also a university that has drafted a social report for one year $(2015)$ and a university that prepared a social/sustainability report every three years $(2013,2016,2019)$.

Finally, Table 2 evidences that 6 universities ( 60 per cent) provide a specific web-section illustrating the main initiatives and measures implemented to cope with the emergency caused by COVID-19. The COVID-19 crisis has deeply impacted all the sustainability dimensions $[6,7]$. Universities have been called to assume a leading role in fighting against the global health crisis, promoting sustainable development models and providing concrete solutions to support the ecosystem they operate [27]. Being a hot topic, universities' main approach is to provide a link on the home page usually named "COVID-19 updates" or "together, safely". These links lead to a specific section in which the university conveys stakeholders all the information regarding measures adopted to ensure that all university activities being pursued in safety (e.g., information on safety and prevention measures; smart working; access to the university; learning at a distance and so on). Other universities prefer to provide separate links to the initiatives implemented during the global crisis (e.g., specific sections devoted to the research projects developed to fight the pandemic).

\subsection{Specific Aspects of Web-Based Sustainability Reporting}

Table 3 summarises the overall results of the content analysis conducted on sampled Italian public universities' websites.

Table 3. Content analysis summary.

\begin{tabular}{ccccccc}
\hline & Total Items & Mean & $\mathbf{\%}$ & Variance & Min & Max \\
\hline Online sustainability disclosure & 49 & 29 & $59 \%$ & 24.22 & $17(35 \%)$ & $34(69 \%)$ \\
\hline
\end{tabular}

Results provide evidence that, on average, each university discloses about 29 items on its website, covering the $59 \%$ of the total items included in the coding framework. The comprehensiveness of sustainability disclosure provided via the web by Italian public universities is relatively higher than that observed in previous results conducted on standalone sustainability reports $[4,5,10,16,29]$. This confirms universities' movement towards the digitalization of services and reporting practices by adopting innovative ways of collecting and communicating data such as websites [11,14]. Previous research has demonstrated that SR practices at universities, based on stand-alone reports, are still in an early stage in terms of both extent and quality $[4,10,29]$. Several shortcomings mainly related to: the absence of a specific reporting framework; the lack of engagement of stakeholders and the shortage of financial and human resources, persist $[10,12,29]$. Our results demonstrate that websites allow universities to overcome the limitations of stand-alone sustainability reports and enhance their commitment to disclosing information on social and environmental issues to their stakeholders $[11,12,14]$. By enabling universities to convey information on sustainability issues in a timely, cheaper, and more visual manner than other commu- 
nication tools, websites facilitate the connection with the external environment and the dialogue with stakeholders [11,14]. Discharging greater accountability and transparency on sustainability issues via the web, facilitates, in turn, universities in gaining more legitimacy for their activities and succeeding in society, offering, at the same time, an image of socially responsible entities [5,11,12].

Figure 1 mirrors the incidence of the 49 items, divided into 8 categories, highlighting the percentage of issues disclosed in each category by sampling universities.

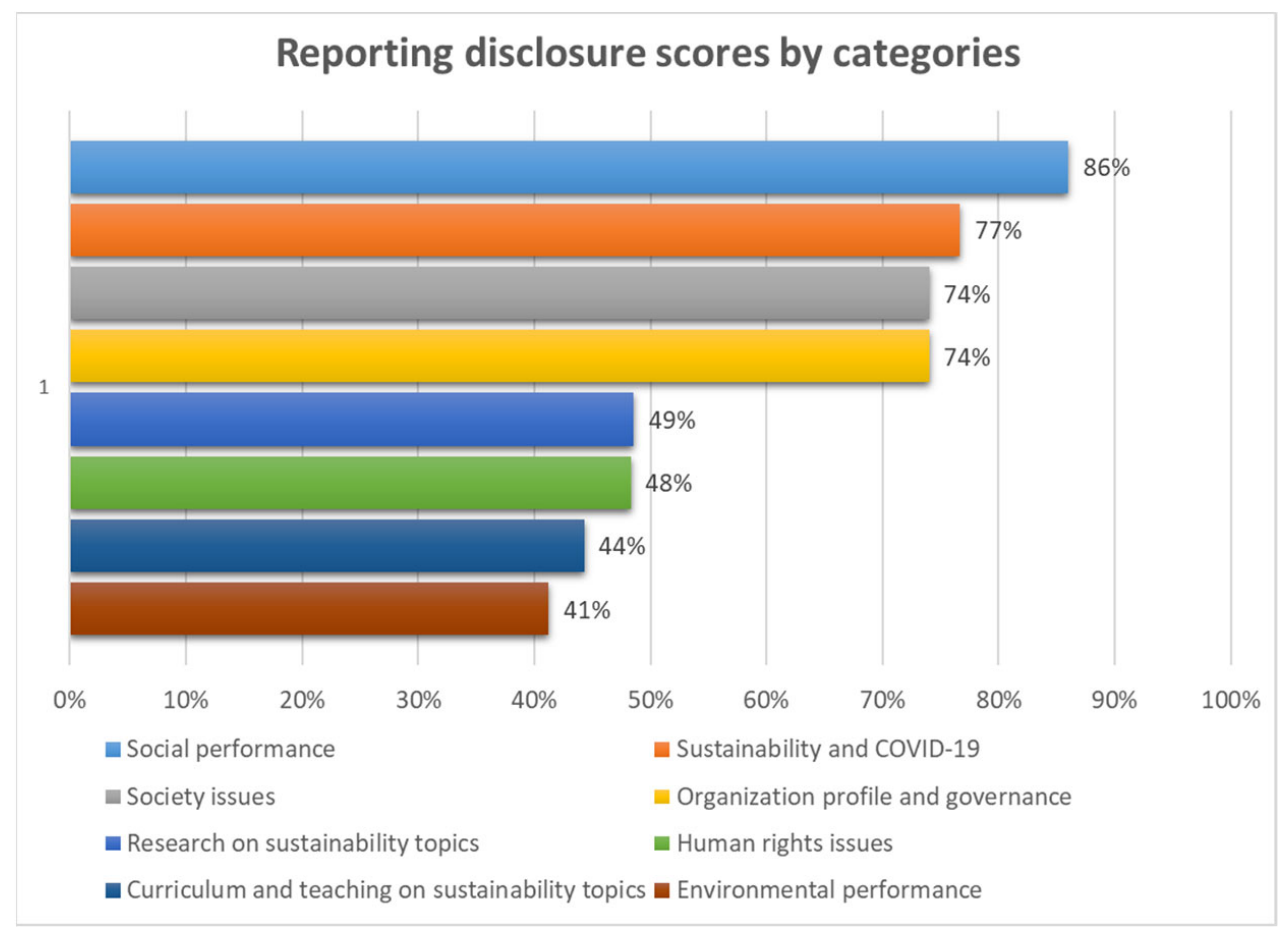

Figure 1. Reporting disclosure scores by categories.

The first category of information more disclosed by the websites of the sampling universities is the "social performance" (86\%), followed by the "sustainability and COVID19 " $(77 \%)$, "social issue" (74\%) and "organization profile and governance" $(74 \%)$.

Therefore, the universities' websites analyzed disclose, on average, $86 \%$ of the social information searched. In contrast with previous studies $[9,10,16,29]$, which, focusing on stand-alone sustainability reports, detected a prevalence of disclosures addressing the environmental disclosure, these findings show a strong commitment towards social issues. This confirms that, due to its peculiar features, websites seem to be a good communication channel in engendering insights for the social issues which involve university and a wider range of stakeholders such as students, researchers, teachers, employee staff and the whole citizen community. In line with An et al. [12], particular attention is devoted to issues such as "occupational health and safety" and "training and education", which are reported by the entire sample. This testifies pivotal attention towards ensuring the growth of human resources, that are the backbone of university teaching and research activities, as well as a need to evidence the creation of safe environments in which researchers and teachers could conduct their activities to the benefit of students and the society at large $[3,9]$. The high score achieved by the category "society issues" and, in particular, by the item "impacts on community" (all universities disclose information on this issue), corroborates these arguments. With the emergence of the third mission, universities are increasingly called to create value for the ecosystem, providing solutions to social problems $[3,10,29]$. Accordingly, conveying information on how a university impacts the community and generates social transformation-through activities such as continuing 
education, technology transfer and innovation, and social engagement-has become crucial to meet stakeholders' information needs [3].

Social issues are also strictly intertwined with the global health crisis triggered by COVID-19. The results provide evidence that Italian public universities use websites to inform stakeholders-particularly students, citizens, and enterprises-about the initiatives put in place to ensure the continuity of teaching, research, and third-mission activities. In particular, the issues related to "Remote/online teaching activities" (100\%); "Prevention measures" (90\%); and, "COVID-19 Research projects" (80\%) are the most disclosed on the websites, often in dedicated sections. This confirms that the core missions of training and educating future leaders and transferring internally produced knowledge to society $[2,10]$, remain crucial in an emergency period. Moreover, universities seem to be particularly attentive in communicating to stakeholders that their research projects and programs are rapidly evolving to deal with COVID-19 issues and, in turn, to support the communities and ecosystem in fighting against the virus.

Consistent with previous studies [5,16], information on "organization profile and governance" also received considerable attention. All sampled universities have disclosed the items "Description of the organization" and "Governance structure or processes". Such information is particularly descriptive and sets the context in which the university operates. Information on governance is notably relevant as SR practices cannot be decoupled from a sound governance system's commitment. University governors are expected to consider the interests of the different stakeholders' groups by ensuring adequate social and environmental disclosure [5,24,28].

Last, it is worth noticing that less than half of the items included in the categories "Research on sustainability topics" and "Curriculum and teaching on sustainability topics" were reported by universities. However, some items embedded in these categories have been significantly addressed by universities. Specifically, information on "Sustainabilityrelated research programs" have been reported by $90 \%$ of the sample. Information on "Courses related to sustainability" and "Degree programs related to sustainability" have been discussed by 8 out of 10 universities $(80 \%)$. For example, from the analysis, it emerged the presence of master degrees such as "Law of sustainable development" or "Environmental Change and Global Sustainability". Also, the presence of information about research projects such as "BIO2ENERGY" and "SELFIE"-aimed at providing solutions to reduce greenhouse gas emissions and create energy-efficient solutions, was detected. This evidence provides arguments supporting the commitment of Italian public universities to incorporate sustainability in both research and teaching programs $[10,29]$.

\section{Conclusions}

This research explores the current status of online sustainability reporting in Italian public universities. The study also examines the university web-based disclosure on the initiatives and measures adopted to deal with COVID-19.

Findings provide evidence that most of the sampled universities present a specific section on their websites dedicated to sustainability disclosure. This means that universities recognize the usefulness of alternative communication technologies as innovative ways to interact with stakeholders regarding sustainability issues.

Results also show that Italian public universities attach pivotal importance to social issues on their websites while partially neglecting environmental performance disclosure. In the social sphere, it has also been considered the information about COVID-19 issues which can be included in the broad sustainability discourse [7]. On this point, results demonstrate that universities exploit websites' potential to inform stakeholders about the initiatives put in place to ensure the continuity of teaching, research, and third mission activities and communicate their commitment to support the community in fighting against the virus.

This research has some implications for academics, university management, and policymakers. Scholars can replicate this study by using the methodology proposed and 
adapting the same framework - including COVID-19 issues-to evaluate the level of online sustainability disclosure in other geographical contexts. Results may also enable regulators, policymakers and university governors to better understand and regulate sustainability reporting practices in Italian public universities. In particular, findings may be beneficial to both policymakers and university governors in gaining awareness about the potential of websites in engendering insights for the social issues which involve the university and a wider range of stakeholders. Accordingly, regulators may reflect on the possibility to enact specific guidelines which may harmonize the sustainability disclosure provided by Italian public universities via online channels. Moreover, this study tries to help university managers and policymakers by developing a framework regarding sustainability dimensions that include COVID-19 as a new attribute of sustainable university practices.

This research also has limitations that may represent starting points for future research. First, due to the complexity and the depth of websites, the sample has been limited to 10 universities. This choice was also motivated by the need to perform updated research, including a hot topic such as COVID-19. Future research could be extended to all Italian public universities, conducting comparisons with universities from other geographical contexts. The second limitation of this research is that-being based on online platforms-it neglects the dynamic changes in sustainability disclosure levels. Moreover, the research adopted a dichotomous approach to examining sustainability disclosures. In future, it may be interesting also to analyze the quality of information and considering the effects of COVID-19 on teaching and third missions.

Author Contributions: “1. Introduction”, G.S. and P.T.P.; “2. Literature review” N.A.; “3. Research methodology” N.A. and G.N.; “4. Results and Discussion” G.N.; “5. Conclusions” G.S. and P.T.P. All authors have read and agreed to the published version of the manuscript.

Funding: This research received no external funding.

Institutional Review Board Statement: Not applicable.

Informed Consent Statement: Not applicable.

Data Availability Statement: The data presented in this study are available on request from the corresponding author.

Conflicts of Interest: The authors declare no conflict of interest.

\section{References}

1. Lozano, R. The state of sustainability reporting in universities. Int. J. Sustain. High. Educ. 2011, 12, 67-78. [CrossRef]

2. Larrán Jorge, M.; Andrades Peña, F.J.; Herrera Madueño, J. An analysis of university sustainability reports from the GRI database: An examination of influential variables. J. Environ. Plann. Manag. 2019, 62, 1019-1044. [CrossRef]

3. Aversano, N.; Nicolò, G.; Sannino, G.; Tartaglia Polcini, P. The Integrated Plan in Italian public universities: New patterns in intellectual capital disclosure. Meditari Account. Res. 2020, 28, 655-679. [CrossRef]

4. Del Sordo, C.D.; Farneti, F.; Guthrie, J.; Pazzi, S.; Siboni, B. Social reports in Italian universities: Disclosures and preparers perspective. Meditari Account. Res. 2016, 24, 91-110. [CrossRef]

5. Moggi, S. Social and environmental reports at universities: A Habermasian view on their evolution. Acc. Forum 2019, 43, 283-326. [CrossRef]

6. García-Sánchez, I.M.; Raimo, N.; Marrone, A.; Vitolla, F. How does integrated reporting change in light of COVID-19? A Revisiting of the content of the integrated reports. Sustainability 2020, 12, 7605. [CrossRef]

7. Ikram, M.; Zhang, Q.; Sroufe, R.; Ferasso, M. The social dimensions of corporate sustainability: An integrative framework including COVID-19 insights. Sustainability 2020, 12, 8747. [CrossRef]

8. Lozano, R.; Llobet, J.; Tideswell, G. Developing a university sustainability report: Experiences from the university of Leeds. In Sustainability Assessment Tools in Higher Education Institutions; Sandra Caeiro, S., Leal Filho, W., Jabbour, C., Azeiteiro, U.M., Eds.; Springer: Cham, Switzerland, 2013; pp. 189-203. [CrossRef]

9. Gamage, P.; Sciulli, N. Sustainability reporting by Australian universities. Aust. J. Pub. Admn. 2017, 76, 187-203. [CrossRef]

10. Sassen, R.; Azizi, L. Assessing sustainability reports of US universities. Int. J. Sustain. High. Educ. 2018, 19, 1158-1184. [CrossRef]

11. Rodríguez Bolívar, M.P.; Garde Sánchez, R.; López Hernández, A.M. Online disclosure of corporate social responsibility information in leading Anglo-American universities. J. Environ. Plan. Manag. 2013, 15, 551-575. [CrossRef]

12. An, Y.; Davey, H.; Harun, H.; Jin, Z.; Qiao, X.; Yu, Q. Online sustainability reporting at universities: The case of Hong Kong. Sust. Acc. Manag. Policy J. 2019, 11, 887-901. [CrossRef] 
13. Navarro-Galera, A.; de Los Ríos, A.; Ruiz, M.; Tirado, P. Transparency of Sustainability Information in Local Governments: English-Speaking and Nordic Cross-Country Analysis. J. Clean. Prod. 2014, 64, 495-504. [CrossRef]

14. Manes Rossi, F.; Nicolò, G.; Tartaglia Polcini, P. New trends in intellectual capital reporting: Exploring online intellectual capital disclosure in Italian universities. J. Intellect. Cap. 2018, 19, 814-835. [CrossRef]

15. Carvalho, A.; Ferreira, M.R.; Lima, S. Web disclosure of institutional information in nonprofit organisations: An approach in Portuguese charities. Int. Rev. Public Nonprofit Mark 2020, 17, 41-58. [CrossRef]

16. Fonseca, A.; Macdonald, A.; Dandy, E.; Valenti, P. The state of sustainability reporting at Canadian universities. Int. J. Sustain. High. Educ. 2011, 12, 22-40. [CrossRef]

17. Sangiorgi, D.; Siboni, B. The disclosure of intellectual capital in italian universities: What has been done and what should be done. J. Intellect. Cap. 2017, 18, 354-372. [CrossRef]

18. Alonso-Almeida, M.M.; Marimon, F.; Casani, F.; Rodriguez-Pomeda, J. Diffusion of sustainability reporting in universities: Current situation and future perspectives. J. Clean. Prod. 2015, 106, 144-154. [CrossRef]

19. Deegan, C. The legitimising effect of social and environmental disclosures. Account. Audit. Account. J. 2002, 15, 282-311. [CrossRef]

20. Ceulemans, K.; Molderez, I.; Van Liedekerke, L. Sustainability reporting in higher education: A comprehensive review of the recent literature and paths for further research. J. Clean. Prod. 2015, 106, 127-143. [CrossRef]

21. Manes-Rossi, F.; Nicolò, G.; Argento, D. Non-financial reporting formats in public sector organisations: A structured literature review. J. Public Budg. Account. Financ. Manag. 2020, 32, 639-669. [CrossRef]

22. Siboni, B.; Del Sordo, C.; Pazzi, S. Sustainability Reporting in State Universities: An Investigation of Italian Pioneering Practices. Int. J. Soc. Ecol. Sustain. Dev. 2013, 4, 1-15. [CrossRef]

23. Gómez, F.U.; Saez-Navarrete, C.; Lioi, S.R.; Marzuca, V.I. Adaptable model for assessing sustainability in higher education. J. Clean. Prod. 2015, 107, 475-485. [CrossRef]

24. Nicolò, G.; Manes-Rossi, F.; Christiaens, J.; Aversano, N. Accountability through intellectual capital disclosure in Italian Universities. J. Manag. Gov. 2020, 24, 1055-1087. [CrossRef]

25. Presidenza del Consiglio dei Ministri. Direttiva del Ministro della Funzione Pubblica Sulla Rendicontazione Sociale Nelle Amministrazioni Pubbliche. 2016. Available online: http:/ /www.funzionepubblica.gov.it/sites/funzionepubblica.gov.it/files/16 887.pdf (accessed on 15 February 2021).

26. GBS. Documento di ricerca $n^{\circ}$ 7, La Rendicontazione Sociale Nelle Universita; Giuffrè Editore: Milano, Italy, 2008.

27. RUS, Rete delle Università per lo Sviluppo Sostenibile. 2020. Available online: https://sites.google.com/unive.it/rus/home (accessed on 15 February 2021).

28. Michelon, G.; Parbonetti, A. The effect of corporate governance on sustainability disclosure. J. Manag. Gov. 2012, 16, 477-509. [CrossRef]

29. Lopatta, K.; Jaeschke, R. Sustainability Reporting at German and Austrian Universities. Int. J. Educ. Econ. Dev. 2014, 5, 66-90. [CrossRef] 